\title{
The Challenge and Its Solution When Determining Biogeochemically Reactive Inorganic Mercury (RHg): Getting the Analytical Method Right
}

\author{
Lian Liang $^{1^{*}}$, Milena Horvat ${ }^{2}$, John Alvarez ${ }^{3}$, Lyman Young $^{3}$, Jože Kotnik $^{2}$, Lisa Zhang ${ }^{1}$ \\ ${ }^{1}$ Cebam Analytical, Inc., Bothell, USA \\ ${ }^{2}$ Department of Environmental Sciences, J. Stefan Institute, Ljubljana, Slovenia \\ ${ }^{3}$ Chevron Energy Technology Company, Richmond, USA \\ Email: *liang@cebam.net
}

Received September 8, 2013; revised October 15, 2013; accepted October 28, 2013

Copyright (C) 2013 Lian Liang et al. This is an open access article distributed under the Creative Commons Attribution License, which permits unrestricted use, distribution, and reproduction in any medium, provided the original work is properly cited.

\begin{abstract}
Biogeochemially reactive inorganic mercury ( $\mathrm{RHg}$ ) is an important fraction of $\mathrm{Hg}$. Researchers have attempted to measure RHg when characterizing Hg-impacted sites, conducting research and development of remediation practices, or evaluating remediation efficiency. In these uses, RHg will be the best choice for analysis in ways that total methyl, and other species of $\mathrm{Hg}$ cannot duplicate. The fraction has been inadequately measured using the $\mathrm{Sn}^{2+}$ reduction method and operationally defined as " $\mathrm{Sn}^{2+}$ reducible $\mathrm{Hg}^{2+}$ ", but the resulting data did not reflect well the nature of the fraction and caused researchers to lose interest, thus limiting the use of RHg in past years. In this work, the problems of using the $\mathrm{Sn}^{2+}$ reduction method were discovered to be generating irreproducible and negatively biased results. Negative bias from $20 \%$ to $99 \%$ was found in different types of waters. To obtain reliable results, an ethylation-based GC-CVAFS method was used to determine RHg. The performance of the method was evaluated by comparing it to the $\mathrm{Sn}^{2+}$ reduction method. Biogeochemically meaningful results have been obtained in the application of the method to determine RHg in mercury mine-impacted waters from the Idrijca River in Slovenia.
\end{abstract}

Keywords: Mercury Speciation; Reactive $\mathrm{Hg}^{2+}$; Method Comparison; Ethylation-GC-CVAFS; $\mathrm{Sn}^{2+}$ Reduction

\section{Introduction}

Methyl mercury $(\mathrm{MeHg})$ is an important species due to its persistence, bioaccumulation and biomagnification, and because of its toxicity to man and ecosystems [1-5]. In past decades, $\mathrm{MeHg}$ and the methylation/demethylation process have drawn significant attention from scientists worldwide. Because of its high solubility, mobility, bioavailability, and especially methylation potential, biogeochemically reactive inorganic mercury $(\mathrm{RHg}$ ) has been recognized to be an important fraction of $\mathrm{Hg}$ for the transformation, reaction, and methylation of $\mathrm{Hg}$ in biogeochemical cycling [6-9]. For characterization and assessment of $\mathrm{Hg}$ impacted sites, research and development of remediation practices, and evaluation of remediation efficiency, RHg may be the best choice for analysis in ways that total methyl, and other species of $\mathrm{Hg}$ cannot duplicate. However, unlike $\mathrm{MeHg}$, RHg measurement

${ }^{*}$ Corresponding author. has not gained widespread acceptance to match its importance, even after over two decades of practice [10]. What is the challenge, and what is the solution?

In the past, in addition to "reactive Hg", $\mathrm{RHg}$ was also defined or described as "easily reducible $\mathrm{Hg}$ ", " $\mathrm{Sn}^{2+}$ reducible Hg", "acid-labile $\mathrm{Hg}$ ", "ionic $\mathrm{Hg}$ ", "labile inorganic Hg", and "bio-available-inorganic Hg" [10,11]. The names related to " $\mathrm{Sn}^{2+}$ reducible" are misleading because RHg can be analyzed by other methods such as the ethylation-based GC-CVAFS method that was the technique used in this work [12-14]. The mechanism of the method is to identify and quantify the fraction of $\mathrm{Hg}^{2+}$ using the ethylation reaction, resulting in ethylatable $\mathrm{Hg}^{2+}$, a proxy for the fraction that is available for abiotic and biotic methylation in an aqueous ecosystem. Those terms related to acid leaching [10] are also misleading because with acid leaching the measured fraction is no longer the naturally-occurring RHg. In this work, $\mathrm{RHg}$ is defined as " $\mathrm{Hg}^{2+}$ that readily enters into chemical 
reactions" [15], and measured analytically in natural waters untreated with any chemicals including acidification for preservation.

Careful selection of an appropriate analytical method is the key to ensuring meaningful results. In the past, the classic $\mathrm{Sn}^{2+}$ reduction method [16] has been virtually the only method used for determination of $\mathrm{RHg}[10,11]$, so $\mathrm{RHg}$ was called " $\mathrm{Sn}^{2+}$ reducible $\mathrm{Hg}$ " 。 There is no doubt that the classic $\mathrm{Sn}^{2+}$ reduction method is a reliable method for determination of $\mathrm{Hg}^{2+}$ in chemically pretreated media such as acid/alkaline digestates or $\mathrm{BrCl}$ / $\mathrm{KMnO}_{4}$ oxidates. However, problems were encountered trying to measure $\mathrm{RHg}$ in waters that were not chemically treated prior to $\mathrm{Sn}^{2+}$ reduction. To gain insight into these problems, this work focused on investigating the effects of analytical conditions on results from the $\mathrm{Sn}^{2+}$ reduction method in comparison with those obtained using an ethylation-based GC-CVAFS method. Since the methodology of the ethylation-based GC-CVAFS method has been detailed in previous publications $[13,14]$, and successfully used to determine $\mathrm{Hg}^{2+}$ in alkaline digestates of biota and blood samples [17,18], the advantage of using this new approach for $\mathrm{RHg}$ was demonstrated by the discovery of bias in the $\mathrm{Sn}^{2+}$ reduction method for the determination of $\mathrm{RHg}$ in environmental waters, and examining whether the data generated was more indicative of the $\mathrm{RHg}$, compared to using the $\mathrm{Sn}^{2+}$ reduction method.

RHg-related studies conducted in past years focused on fresh waters with low levels of $\mathrm{Hg}$ [10], or waters already treated for removal of $\mathrm{Hg}$ [11]. Since $\mathrm{RHg}$ is an important and useful fraction to characterize $\mathrm{Hg}$-impacted sites and evaluate the results of remediation, the present work includes analyses of both fresh waters with $\mathrm{Hg}$ concentration $<12 \mathrm{ng} / \mathrm{L}$ (the lowest Nationwide Criterion, 40 CFR 131.36) and Hg-impacted waters including industrial waste waters. Moreover, as $\mathrm{RHg}$ is the fraction directly linked to methylation and bioavailability, RHg was previously measured mostly in filtered samples, and defined as dissolved $\mathrm{RHg}$ when estimating bioavailable $\mathrm{Hg}[11,15]$. However, methylation can take place with RHg in both filtered waters and particles, so in this work both filtered and unfiltered waters were studied.

To further examine whether the ethylation method can generate meaningful $\mathrm{RHg}$ results to characterize $\mathrm{Hg}$ impacted waters, the method was applied to measurement of $\mathrm{RHg}$ in $\mathrm{Hg}$ mine-impacted waters from the Idrijca River in Slovenia, and results were compared with those for total mercury ( $\mathrm{THg}$ ) and methyl mercury (MeHg) to assess their biogeochemical significance.

\section{Experimental}

\subsection{Sample Collection and Process}

Water samples were collected in glass bottles with Tef- lon-lined caps. Special attention was paid to avoiding contamination according to the procedures described in EPA Method 1669 [19]. For dissolved fractions, the samples were filtered in the field immediately after sample collection using 0.45 um disposable cellulose nitrate vacuum filter units. Unpreserved samples were packed in coolers at $0^{\circ} \mathrm{C}-4^{\circ} \mathrm{C}$ and shipped overnight to the laboratory in Bothell, WA, USA. In most cases, the lab analyzed the samples within 48 hours after receipt. Sample bottles were shaken vigorously prior to sub-sampling.

\subsection{Instrumentation, Standards, and Reagents}

For standards and reagents, only those specifically prepared for this work are addressed here, while others not mentioned are detailed in EPA method 1631 [20] or 1630 [21].

\subsubsection{Instrumentation}

A cold vapor atomic fluorescence spectrometry (CVAFS) analytical system utilizing a BR III Hg analyzer (Brooks Rand, Seattle, USA) was employed for determination of $\mathrm{Sn}^{2+}$ reduced $\mathrm{Hg}^{0}$ [20,22]. A lab-built GC/CVAFS system with a BR III $\mathrm{Hg}$ analyzer was used for separation and detection of ethylation derivatives of $\mathrm{MeHg}$ or $\mathrm{RHg}$ [14,21]. An AB15 pH meter (Accumet) was used for $\mathrm{pH}$ measurement.

\subsubsection{Standards}

A $1000 \mathrm{ug} / \mathrm{mL} \mathrm{Hg}^{2+}$ stock standard was prepared by dissolving $0.1353 \mathrm{~g} \mathrm{HgCl}_{2}$ (Sigma-Aldrich) into $100 \mathrm{~mL}$ of $5 \% \mathrm{HNO}_{3}$. A working standard of $10 \mathrm{ng} / \mathrm{mL} \mathrm{Hg}^{2+}$ in $0.2 \% \mathrm{HNO}_{3}$ was prepared from the stock solution by dilution.

\subsubsection{Buffer}

A $0.5 \mathrm{M}$ citrate buffer was prepared by dissolving $270 \mathrm{~g}$ of reagent grade citric acid $\left(\mathrm{C}_{6} \mathrm{H}_{8} \mathrm{O}_{7} \cdot \mathrm{H}_{2} \mathrm{O}\right)$ and $370 \mathrm{~g}$ of reagent grade sodium citrate $\left(\mathrm{C}_{6} \mathrm{H}_{5} \mathrm{Na}_{3} \mathrm{O}_{7} \cdot 2 \mathrm{H}_{2} \mathrm{O}\right)$ into DDW to make a $2.5-\mathrm{L}$ solution.

\subsection{Analytical Procedures}

In what follows, $\mathrm{RHg}$ determined by the ethylation method is designated "EtRHg", while that determined by $\mathrm{Sn}^{2+}$ reduction is designated "SnRHg".

\subsubsection{Determination of EtRHg}

Appropriate aliquots up to $40 \mathrm{~mL}$ of unpreserved sample were placed into bubblers, depending on the RHg concentration, and distilled, deionized water (DDW) was added to bring the total volume to $50 \mathrm{~mL} .1 \mathrm{~mL}$ of $0.5 \mathrm{M}$ citrate buffer was added, followed by $0.05 \mathrm{~mL}$ of freshly thawed 1\% NaBEt4 solution [21]. The bubblers were immediately capped and shaken. The bubblers sat at 
room temperature for $20 \mathrm{~min}$ as the ethylation reaction proceeded. Then the samples were purged with $\mathrm{N}_{2}$ at 200 $\mathrm{mL} / \mathrm{min}$ for $20 \mathrm{~min}$. The ethylation derivatives purged from the bubblers were collected onto Tenax traps, and finally analyzed by GC/CVAFS [14,21]. The $10 \mathrm{ng} / \mathrm{mL}$ $\mathrm{Hg}^{2+}$ working standard was used for calibration. The method detection limit (MDL) is $0.05 \mathrm{ng} / \mathrm{L}$.

\subsubsection{Determination of SnRHg}

Appropriate aliquots up to $100 \mathrm{~mL}$ of unpreserved sample were placed into bubblers, depending on the $\mathrm{RHg}$ concentration. DDW was added to bring the total volume to $100 \mathrm{~mL}$. $0.2 \mathrm{~mL}$ of $25 \% \mathrm{SnCl}_{2}(\mathrm{w} / \mathrm{v})$ in $20 \% \mathrm{HCl}$ was added. The samples were purged with $\mathrm{N}_{2}$ at $300 \mathrm{~mL} / \mathrm{min}$ for $20 \mathrm{~min}$ to remove $\mathrm{Sn}^{2+}$ reduced $\mathrm{Hg}^{0}$. The purged $\mathrm{Hg}^{0}$ was collected on gold traps and then analyzed by CVAFS $[20,22]$. The MDL is $0.2 \mathrm{ng} / \mathrm{L}$.

\subsubsection{Determination of $\mathrm{THg}$}

Samples were oxidized with $\mathrm{BrCl}$ overnight, and excess $\mathrm{BrCl}$ was reduced with $\mathrm{NH}_{2} \mathrm{OH}$ solution prior to analysis $[20,22]$. Appropriate sample aliquots depending on $\mathrm{THg}$ concentration were placed into bubblers, and DDW was added to adjust the volume to $100 \mathrm{~mL}$. Samples were then purged and $\mathrm{Hg}^{0}$ was quantified as described above for the SnRHg procedure. The MDL is $0.2 \mathrm{ng} / \mathrm{L}$.

\subsubsection{Determination of $\mathrm{MeHg}$}

Samples were acidified to $4 \% \mathrm{HNO}_{3}$, then allowed to sit overnight or longer at room temperature prior to sample preparation and analysis using EPA 1630 [21]. The MDL is $0.02 \mathrm{ng} / \mathrm{L}$.

\subsection{Experiments Examining the Effects of Analytical Conditions on the $\mathrm{Sn}^{2+}$ Reduction Method}

\subsubsection{The Effect of $\mathrm{pH}$}

Fourteen 500-mL bottles were prepared, each containing $400 \mathrm{~mL} \mathrm{DDW}$ and $0.8 \mathrm{~mL} 25 \% \mathrm{SnCl}_{2}(\mathrm{w} / \mathrm{v}$, in $20 \% \mathrm{HCl})$. Diluted $\mathrm{NaOH}$ and $\mathrm{HCl}$ solutions were used to adjust the $\mathrm{pH}$ of these samples within a range of 2 to 13 . From each bottle, 3 aliquots of $100 \mathrm{~mL}$ each were transferred into 3 pre-cleaned bubblers. Two of the bubblers were spiked with $280 \mathrm{pg}$ of $\mathrm{Hg}^{2+}$ standard in $0.04 \mathrm{~mL} 0.2 \% \mathrm{HNO}_{3}$ solution, while the third bubbler served as a blank. Samples in the bubblers were analyzed for $\mathrm{Sn}^{2+}$ reducible $\mathrm{Hg}$ by purge/trap/CVAFS. The $\mathrm{pH}$ of each sample was measured after purging.

\subsubsection{The Effect of $\mathrm{SnCl}_{\mathbf{2}}$ Concentration}

A 2.0 L glass volumetric flask was half-filled with DDW, and $2 \mathrm{~mL}$ of concentrated $\mathrm{HNO}_{3}$ and $5.6 \mathrm{ng}$ of $\mathrm{Hg}^{2+}$ standard were added. The flask was then filled to the neck with DDW and shaken. The $\mathrm{Hg}^{2+}$ concentration in this sample was $2.8 \mathrm{ng} / \mathrm{L}$. Aliquots of $100 \mathrm{~mL}$ were placed into bubblers, and then various volumes $(0.05,0.10,0.20$, $0.40,0.60,0.80$, and $1.00 \mathrm{~mL})$ of $25 \% \mathrm{SnCl}_{2}(\mathrm{w} / \mathrm{v}$, in $20 \% \mathrm{HCl}$ ) were added, corresponding to $\mathrm{SnCl}_{2}$ concentrations of $0.013,0.025,0.050,0.100,0.150,0.200$, and $0.250 \%(\mathrm{w} / \mathrm{v})$. These samples were then analyzed for $\mathrm{Hg}^{2+}$ by purge/trap/CVAFS. Analyses were performed in duplicate for each $\mathrm{SnCl}_{2}$ concentration.

\subsubsection{The Effect of Purge Gas Rate and Purge Time}

Municipal waste water was collected in a 4-L glass bottle. Observable particles in the water were removed by filtration using thin paper napkins. Filtration blanks showed no significant $\mathrm{Hg}$ concentration. Concentrations of EtRHg and $\mathrm{THg}$ in the sample were determined at the optimal conditions of the methods, and found to be 13.54 $\pm 0.62 \mathrm{ng} / \mathrm{L}(\mathrm{n}=6)$ and $34.7 \pm 1.4 \mathrm{ng} / \mathrm{L}(\mathrm{n}=6)$, respectively. The sample was then analyzed for $\mathrm{THg}$ and SnRHg at various purge gas flow rates and purge times. The analysis was performed in duplicate under each analytical condition, and the mean value of duplicate results was calculated. Recoveries of $\mathrm{THg}$ at various conditions were calculated relative to the result $(34.7 \mathrm{ng} / \mathrm{L})$ determined at optimal conditions, while $\mathrm{SnRHg}$ recoveries were calculated relative to the optimal EtRHg result (13.54 ng/L).

\subsubsection{The Effect of Purge Time on Recovery of SnRHg in River Waters with Low Level Hg}

Twelve river water samples were collected, and each was analyzed for SnRHg using two different purge times (20 min and $40 \mathrm{~min}$ ). These samples were visually clear (total suspended solids (TSS) $<4 \mathrm{mg} / \mathrm{L}$ ), and THg concentrations ranged from 1 to $8 \mathrm{ng} / \mathrm{L}$. Unfiltered and unpreserved waters were analyzed. EtRHg concentrations in these waters were also determined, and the results were used as benchmarks for calculating the recoveries of SnRHg for different purge times. All samples were analyzed in duplicate for both EtRHg and SnRHg, while matrix spike (MS) measurements were performed on each sample only for EtRHg analysis, to examine matrix interferences.

\subsubsection{The Effect of Purge Time on Recoveries of SnRHg in Hg Impacted Waters}

Twelve industrial waste water samples collected from a waste treatment site were used for the experiment. These samples looked clear (TSS $<5 \mathrm{mg} / \mathrm{L}$ ), and THg concentrations ranged from 5 to $100 \mathrm{ug} / \mathrm{L}$. Unpreserved and unfiltered samples were analyzed for SnRHg using two different purge times (20 min and 48 hours). These samples were also analyzed for EtRHg, and the EtRHg concentrations were used for calculating $\mathrm{SnRHg}$ recoveries. All samples were analyzed in duplicate for both EtRHg 
and SnRHg, while MS measurements were again performed only for EtRHg analyses.

\subsubsection{The Behavior of Purging SnRHg from a Typical Complex Matrix}

A Hg-impacted industrial waste water sample was used for the experiment. The sample looked dirty and contained some suspended solids. The sample was shaken vigorously prior to sub-sampling, then analyzed for $\mathrm{THg}$, $\mathrm{MeHg}$, and EtRHg; concentrations were $6.16 \mathrm{ug} / \mathrm{L}, 2.96$ $\mathrm{ng} / \mathrm{L}$, and $2.97 \mathrm{ug} / \mathrm{L}$, respectively. $3 \mathrm{~mL}$ of well-mixed, unpreserved, and unfiltered water was added to $50 \mathrm{~mL}$ DDW in a bubbler for reaction with $0.2 \mathrm{~mL}$ of $\mathrm{SnCl}_{2}$ $(25 \%, \mathrm{w} / \mathrm{v}$, in $20 \% \mathrm{HCl})$. The $20 \mathrm{~min}$ purge/trap/measurement procedure was then repeated over and over, one time after another. After 24 cycles, with $\mathrm{Hg}^{0}$ still coming out of the sample and no idea how many more cycles would be needed, the bubbler was purged for 4 hours for the $25^{\text {th }}$ cycle. Finally, the $26^{\text {th }}$ cycle of $20 \mathrm{~min}$ showed no detectable $\mathrm{Hg}^{0}$, suggesting that $\mathrm{RHg}$ and $\mathrm{Hg}^{0}$ had been completely removed.

\subsubsection{The Stability of RHg in Unpreserved Waters}

Six unpreserved river water samples with various concentrations of RHg were collected in 1-L glass bottles and shipped to the lab overnight, on ice. The samples looked clear (TSS $<7 \mathrm{mg} / \mathrm{L}$ ), suggesting the sample matrices might not be complex. The samples were allowed to warm to $20^{\circ} \mathrm{C}$ after receipt, and then analyzed for EtRHg. The analyses were carried out multiple times for each sample, at 4, 24, 48, and 72 hours after sample receipt. All analyses were performed in duplicate and the mean value of duplicate results was calculated. Samples were well-mixed prior to sub-sampling.

\section{Results and Discussion}

\subsection{Effect of Analytical Conditions on the Results for $\mathrm{Hg}^{2+}$ Using the $\mathrm{Sn}^{2+}$ Reduction Method}

The effects of $\mathrm{pH}$ and $\mathrm{SnCl}_{2}$ concentration on the results of the $\mathrm{Sn}^{2+}$ reduction method are shown in Figure 1. It is worth noting here that the analyte is $\mathrm{Hg}^{2+}$ rather than $\mathrm{RHg}$ because this experiment is designed to examine whether $\mathrm{pH}$ or the $\mathrm{SnCl}_{2}$ concentration effect results during $\mathrm{Sn}^{2+}$ reduction. Here, the reaction matrix was DDW rather than natural water, and the $\mathrm{Hg}^{2+}$ was not naturally occurring $\mathrm{RHg}$. For the effect of $\mathrm{pH}$, each point is the mean of the results from two duplicate samples. The relative percent difference (RPD) between duplicate samples was $<5 \%$ for 14 samples at various $\mathrm{pH}$ levels. The average recovery of $\mathrm{Hg}^{2+}$ was $100.8 \% \pm 2.7 \%(\mathrm{n}=$ 14), indicating the results are independent of $\mathrm{pH}$. For the effect of the $\mathrm{SnCl}_{2}$ concentration, average recovery was
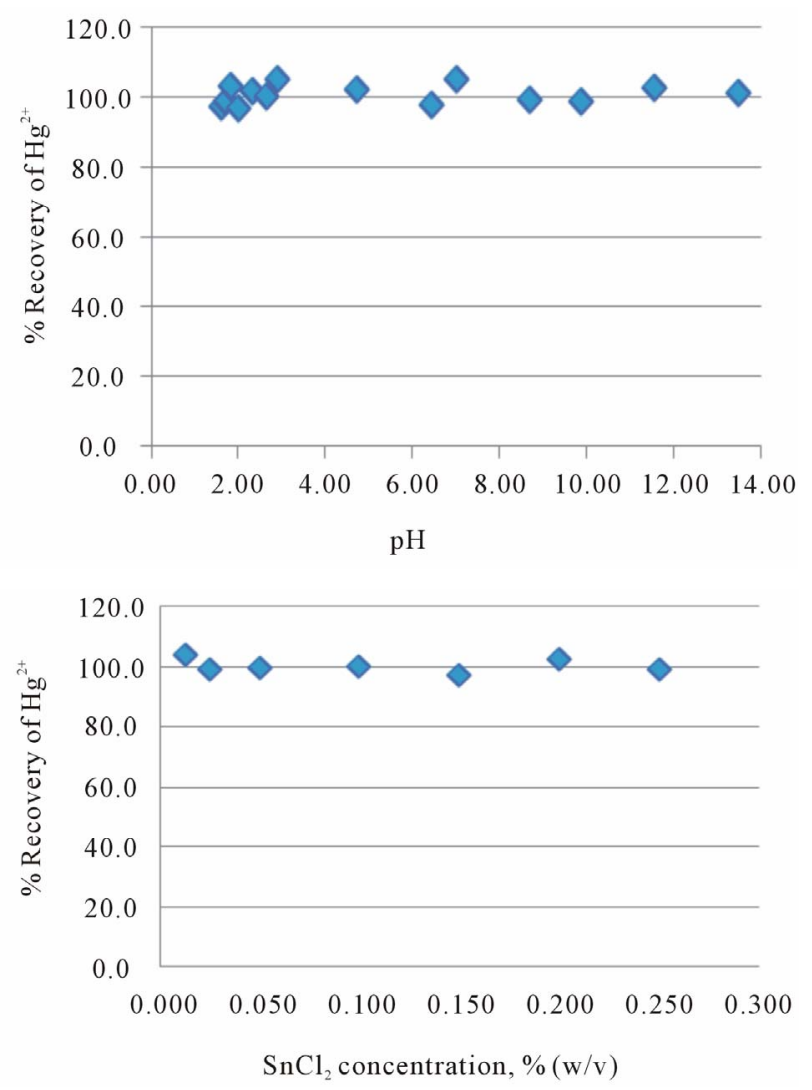

Figure 1. The effect of $\mathrm{pH}$ and $\mathrm{SnCl}_{2}$ concentration on results of $\mathrm{Hg}^{2+}$.

$100.4 \pm 2.23 \%(n=7)$ with $\mathrm{RSD}=2.2 \%$, indicating that the $\mathrm{SnCl}_{2}$ concentration in the range tested does not affect the results for $\mathrm{Hg}^{2+}$. The results shown in Figure 1 clearly indicate that the "chemically-related factors" of $\mathrm{pH}$ and $\mathrm{SnCl}_{2}$ concentration do not affect the $\mathrm{Hg}^{2+}$ results. In contrast, it was found that the "physical factors" of purge gas flow rate and purge time critically affect the results (Figure 2).

For the effect of gas flow rate shown in Figure 2, for $\mathrm{THg}$, the recovery increased with increasing gas flow rate before reaching $100 \%$ recovery at flow rates between 260 to $370 \mathrm{~mL} / \mathrm{min}$. $370 \mathrm{~mL} / \mathrm{min}$ is the highest useable flow rate without breakthrough using our gold traps (Cebam Analytical, Inc.), then recoveries decreased at higher flow rates; for $\mathrm{SnRHg}$, the recovery also increased with increasing gas flow rate, but the highest recovery was found to be only around $40 \%$, and lower values were recorded with further increases in flow rate, again due to breakthrough. This indicated that for SnRHg analysis with a purge time of $20 \mathrm{~min}$ at the highest flow rate allowed, only $40 \%$ of the $\mathrm{SnRHg}$ in this sample was recovered; i.e., the result was negatively biased by $60 \%$. Because there is no range of flow rates at which a plateau in the recovery data is established, it would be difficult to obtain reproducible results for replicate analyses. This 

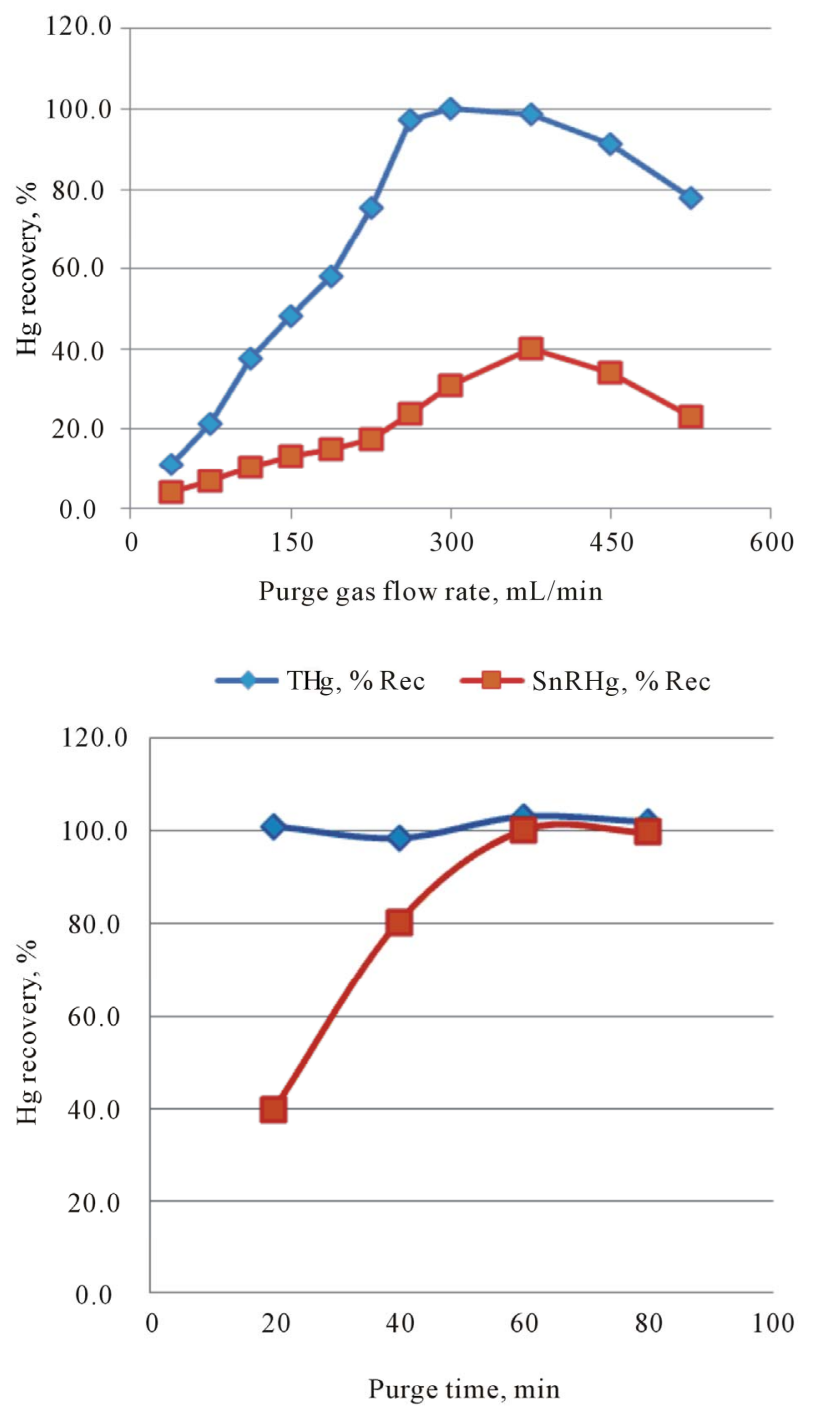

$\longrightarrow$ THg Rec., \% —-SnRHg Rec., \%

Figure 2. Effect of purge gas flow rate (purge time $20 \mathrm{~min}$ ), and purge time on $\mathrm{Hg}$ recovery (purge flow rate $350 \mathrm{~mL}$ / min).

explains why previous results using the $\mathrm{Sn}^{2+}$ reduction method were found to be irreproducible and imprecise.

For the effect of purge time (Figure 2), 100\% recovery of SnRHg can be obtained only when the sample is purged for long enough and insufficient purge time leads to lower results for SnRHg. This raises the question of why 20 min was enough to purge the $\mathrm{Sn}^{2+}$-reduced $\mathrm{Hg}^{0}$ for analysis of $\mathrm{THg}$ (reaching 100\% recovery), but a longer time was required for analysis of SnRHg using the same technique. The only difference in the analytical procedures between $\mathrm{THg}$ and $\mathrm{SnRHg}$ is that for $\mathrm{THg}$, $\mathrm{Sn}^{2+}$ reduction was carried out in samples which had been oxidized (or digested) with oxidants such as $\mathrm{BrCl}$ [20], $\mathrm{KMnO}_{4}, \mathrm{H}_{2} \mathrm{SO}_{4}, \mathrm{HNO}_{3}$ (used by many EPA THg methods), or others, while for SnRHg, the samples were unpreserved and untreated chemically prior to $\mathrm{Sn}^{2+}$ reduction. It was also found that purging $\mathrm{Sn}^{2+}$-reduced $\mathrm{Hg}^{0}$ from DDW required as much purge time as the oxidized/digested medium. Thus, recovering $\mathrm{Sn}^{2+}$-reduced $\mathrm{Hg}^{0}$ from an unpreserved/undigested medium required a longer purge time than from an oxidized/digested medium or from DDW. The reason for this will be discussed below.

\subsection{The Effect of Purge Time on Results of SnRHg Analysis of River and Industrial Waste Waters}

To confirm the effect of purge time on the results of $\mathrm{SnRHg}$ analysis, more natural river waters with low $\mathrm{Hg}$ concentrations and $\mathrm{Hg}$-impacted industrial waste waters with high $\mathrm{Hg}$ concentrations were analyzed by the $\mathrm{Sn}^{2+}$ reduction method. Figure 3 shows the effect of purge time on SnRHg results for 12 river water samples. For these relatively clean waters, a 20 -min purge recovered about $80 \%$ of the RHg, i.e. a negative bias of about $20 \%$. For filtered natural waters, similar patterns were observed. However, for the highly contaminated industrial waste waters with complex matrices (Figure 4), for a purge time of 20 min recovered only very small fractions $(0.7 \%$ to $1.9 \%)$ of the $\mathrm{RHg}$, but after purging for 48 hours, $100 \%$ recoveries were reached. This reveals how severely biased previous results may have been when the $\mathrm{Sn}^{2+}$ reduction method was used for $\mathrm{Hg}$-impacted waters. $100 \%$ recovery can only be reached when the sample is purged for a long enough time. How can we tell if the $\mathrm{RHg}$ is recovered completely by this method? By purging a sample for a cycle time such as $20 \mathrm{~min}$, the $\mathrm{Hg}$ collected on the trap may be measured, and then a new trap is used for the next purge cycle. This is continued until the $\mathrm{Hg}$ collected on a trap is not detectable. Then the $\mathrm{Hg}$ loaded on all the traps is summed to yield the result for RHg in the sample.

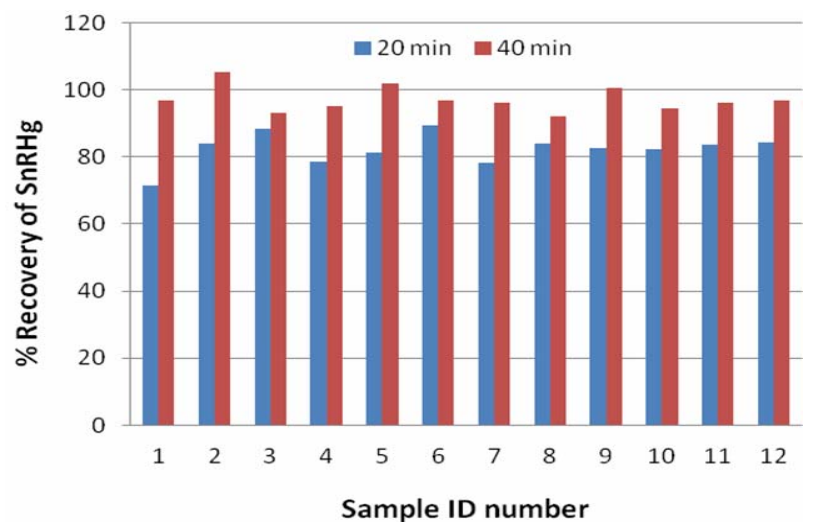

Figure 3. Effect of purge time on recoveries of SnRHg in 12 river water samples. 


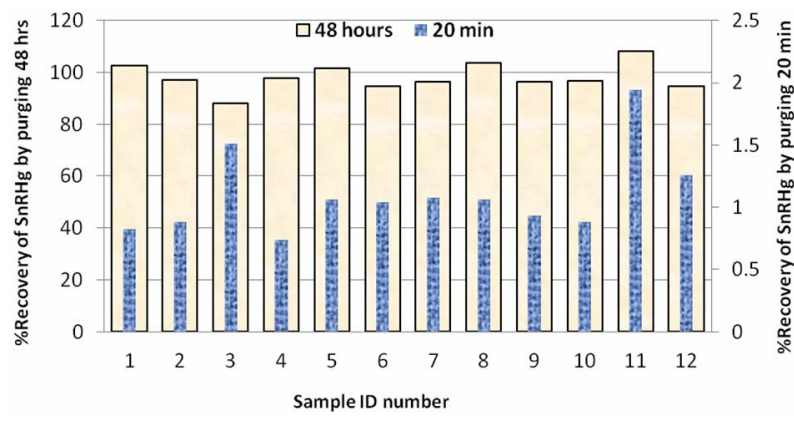

Figure 4. The effect of purge time on the recoveries of $\mathrm{SnRHg}$ in $12 \mathrm{Hg}$ impacted industrial waster waters.

\subsection{Purging $\mathrm{Sn}^{2+}$-Reduced $\mathrm{Hg}^{0}$ from Industrial Waste Waters Having High $\mathrm{Hg}$ Concentrations and Complex Matrices}

To get clearer insight into the purging behavior of $\mathrm{Sn}^{2+}$ reduced $\mathrm{Hg}^{0}$ another experiment was conducted using an Hg-impacted industrial waste water sample (Figure 5). The sample was purged for 26 cycles as described above and the concentration of $\mathrm{RHg}$ in the sample was calculated by summing the mass of $\mathrm{RHg}$ recovered over all cycles; the result was found to be $2.99 \mathrm{ug} / \mathrm{L}$.

Here, it is worth emphasizing that the concentration of RHg by $\mathrm{Sn}^{2+}$ reduction was found to be equivalent to the EtRHg concentration in the sample, i.e., $\mathrm{SnRHg} \approx \mathrm{EtRHg}$. This confirmed the finding in the low level $\mathrm{Hg}$ samples (Figure 3), and the Hg-impacted samples (Figure 4), as well as other samples investigated when samples were purged for long enough: The two independently-defined quantities based on two different chemical reactions, ethylation and $\mathrm{Sn}^{2+}$ reduction, were found to represent the same fractions, RHg.

Further consideration of the results in Figure 5 show: 1) the sum of RHg purged from the $1^{\text {st }}$ to the $24^{\text {th }}$ cycle was $6707 \mathrm{pg}$, the average was $279 \mathrm{pg}$ per cycle, and the RSD was $7.7 \%$, indicating that $\mathrm{Sn}^{2+}$-reduced $\mathrm{Hg}^{0}$ was purged out steadily over time; and 2) the mass of $\mathrm{RHg}$ purged in the $25^{\text {th }}$ cycle was $2270 \mathrm{pg}$, and, according to the average rate of the first 24 cycles, 3 hours would have been enough for the $25^{\text {th }}$ cycle. Again, the relationship SnRHg $\approx$ EtRHg can be established only when the sample is purged long enough to ensure the $\mathrm{Sn}^{2+}$-reduced $\mathrm{Hg}^{0}$ is purged out completely.

The behavior shown in Figure 5 was similarly found in purging naturally occurring $\mathrm{Hg}^{0}$ from various $\mathrm{Hg}$-impacted waste waters, and also found by Horvat [23] in measurements of $\mathrm{Hg}^{0}$ evasion in $\mathrm{Hg}$-impacted river waters. The analysis of $\mathrm{Hg}^{0}$ requires only the purge/trap step prior to CVAFS detection; there were no chemical reactions/treatments involved. This may suggest that the long purge time required was for the isolation of $\mathrm{Hg}^{0}$ from the sample medium, regardless of any chemical processes. Based on the nature of $\mathrm{Hg}^{0}$, it may be adsorbed to or-

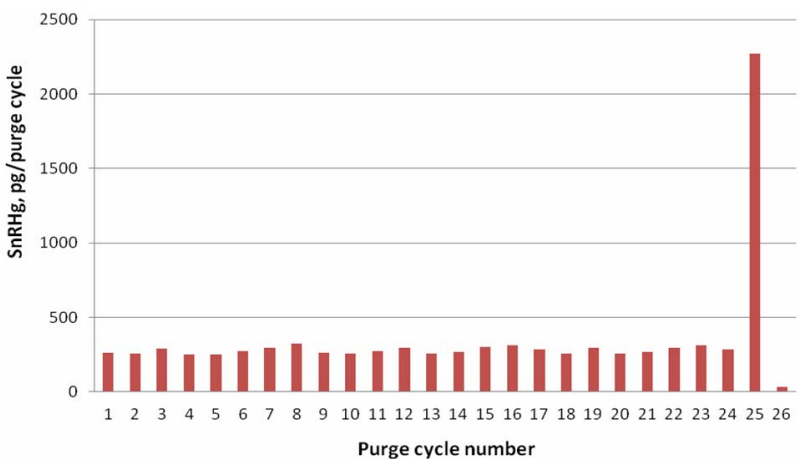

Figure 5. Behavior of purge $8977 \mathrm{pg}$ of $\mathrm{Hg}^{0}$ reduced by $\mathrm{Sn}^{2+}$ from $3 \mathrm{~mL} \mathrm{Hg}$ contaminated water, the 25th purge cycle is 4 hours, other $20 \mathrm{~min}$.

ganic/inorganic substances in the medium, and this binding makes purging the $\mathrm{Hg}^{0}$ difficult. Conversely, the purging of $\mathrm{Hg}^{0}$ from DDW requires less time compared to unpreserved/undigested water because $\mathrm{Hg}^{0}$ occurs free of binding in DDW. An additional or alternative explanation for this observation is that the binding between $\mathrm{RHg}$ and natural organic material (NOM) makes $\mathrm{RHg}$ resistant to reduction by $\mathrm{Sn}^{2+}$ [24-26].

Moreover, as mentioned above, isolating $\mathrm{Sn}^{2+}$-reduced $\mathrm{Hg}^{0}$ from DDW required the same purge times as from oxidized/digested medium. Thus, $\mathrm{Hg}^{0}$ is also present free of binding in oxidized/digested medium, suggesting that this apparent binding mechanism can be destroyed by oxidation/digestion, setting $\mathrm{Hg}^{0}$ free in the medium. This also explains the difference in recoveries between $\mathrm{THg}$ and RHg in Figures $\mathbf{4}$ and 5, where THg can be fully recovered easily by a $20 \mathrm{~min}$ purge, but $\mathrm{SnRHg}$ cannot.

In addition to the negative bias described above, there is potentially a positive bias when waters contain naturally occurring $\mathrm{Hg}^{0}$ or dimethyl $\mathrm{Hg}$. It is clear that these species may also be purged, collected, and measured together with $\mathrm{Sn}^{2+}$-reduced $\mathrm{Hg}^{0}$. This positive bias will be discussed below.

\subsection{Matrix Interference in the Ethylation Method}

Matrix interference with the ethylation reaction is a potential problem in the determination of $\mathrm{MeHg}$ in various matrices [17,18,21], and the same applies to RHg. This is why distillation or other techniques were developed for the isolation of $\mathrm{MeHg}$ from matrices prior to ethylation $[27,28]$. However, existing techniques for the isolation of $\mathrm{MeHg}$ cannot be applied for the isolation of $\mathrm{RHg}$ because the nature of this fraction will change during processing. Fortunately, matrix interference of the ethylation reaction was found to be easily eliminated by simply diluting the samples. The ratio of $\mathrm{RHg}$ to $\mathrm{MeHg}$ generally ranges from 10 to $10^{\mathrm{n}}$ depending on the site, and the more impacted the site is, the greater the value of $n$. This allows 
diluted samples to be analyzed without matrix interference $[29,30]$. The lowest $\mathrm{RHg}$ concentrations were found to be $>0.5 \mathrm{ng} / \mathrm{L}$, which is about 10 times the MDL, 0.05 $\mathrm{ng} / \mathrm{L}$. Matrix interference was determined by analyzing samples spiked with $\mathrm{Hg}^{2+}$ standard. Spike recoveries ranging within $75 \%$ to $125 \%$ were considered to show no matrix interference. In the experiments on the effect of purge time on the recovery of SnRHg, a MS sample was analyzed for each sample for determination of EtRHg. MS recoveries for 12 unfiltered river samples were found to range from $83 \%$ to $107 \%$, while recoveries of $91 \%$ to $112 \%$ were found for 12 industrial waste water samples. The industrial waste waters were analyzed after dilution by up to 1000 or more times.

\subsection{Stability of RHg in Unpreserved Water Samples}

The results shown in Figure 6 indicate that $\mathrm{RHg}$ was stable at $20^{\circ} \mathrm{C}$ for at least 72 hours after sample receipt. If the sample shipping time was 24 hours, the samples would thus have been stable for 96 hours after collection. The samples used here were relatively clear, with TSS < $7 \mathrm{mg} / \mathrm{L}$, suggesting that the sample matrices were not complex. Since the stability of RHg may depend strongly on various biogeochemical factors, its relative stability in these water samples for 96 hours does not necessarily ensure its stability in other samples. To obtain reliable results, water samples should be analyzed as soon as possible after sample collection. Freezing of samples is not recommended because adsorption of $\mathrm{RHg}$ on the container wall could increase with decreasing temperature.

Generally, water samples for analysis of trace metals are preserved with acids such as $\mathrm{HNO}_{3}$ and $\mathrm{HCl}$ to maintain the stability of the analytes for a longer time. In past years, water samples analyzed for $\mathrm{RHg}$ were sometimes acidified with $\mathrm{HCl}$ prior to analysis [31-34]. However, to maintain the original state of the $\mathrm{RHg}$, water samples

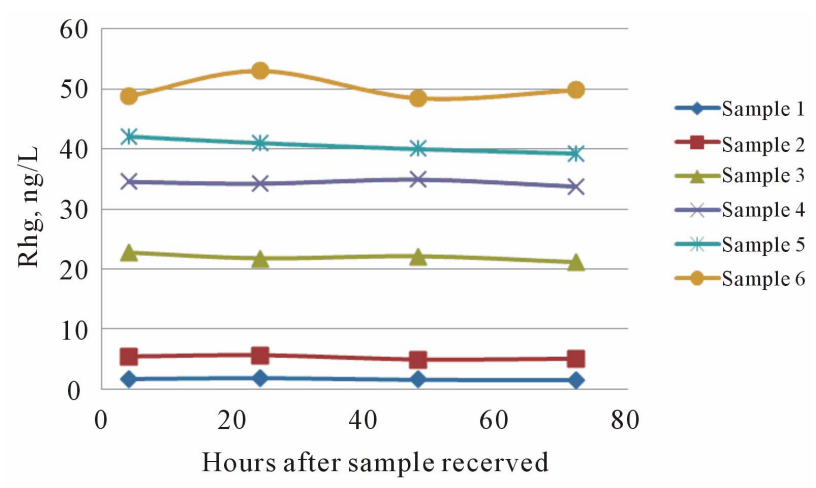

Figure 6. Observation of stability of $\mathrm{RHg}$ in unpreserved surface water at $20^{\circ} \mathrm{C}$. should not be preserved. Nevertheless, waters acidified to $4 \% \mathrm{HNO}_{3}$ or $\mathrm{HCl}$ were also investigated in this work, and results around 30\% lower than those found in unpreserved waters were observed. This result is similar to that reported by Bloom [10]. $\mathrm{MeHg}$ was also involved in these experiments, but in contrast to $\mathrm{RHg}$, higher results for $\mathrm{MeHg}$ were found in acidified waters.

\subsection{Application of the Ethylation Method to the Determination of $\mathbf{R H g}$ in $\mathbf{H g}$-Impacted Waters from the Idrijca River, Slovenia}

The Idrijca River in Slovenia drains the area of the Idrija $\mathrm{Hg}$ mine, now closed but formerly the world's second largest $\mathrm{Hg}$ mine. Five sampling locations were selected along the Idrijca River (Figure 7), representative of different levels of $\mathrm{Hg}$ impact as determined by previous studies [15,35-39]. The first location, above the Belca inflow, is a pristine site with very low $\mathrm{Hg}$ contamination, while all the downstream sampling sites are affected by the Hg mine to some extent [36]. The second site, in the town of Idrija, is where the mine drainage enters the river. The third location, above the town of Spodnja Idrija, is situated approximately $200 \mathrm{~m}$ downstream of the outflow of a municipal wastewater treatment plant. The fourth site, Kozarska grapa, is approximately $15 \mathrm{~km}$ downstream from Spodnja Idrija in a rural area; and Bača pri Modreju, the final sampling site, is about $1 \mathrm{~km}$ upstream of the confluence of the Idrijca River with the Soča River (Isonzo). The $\mathrm{pH}$ in the river is between 7.73 and 8.82, and the solute composition is dominated by $\mathrm{HCO}_{3}^{-}, \mathrm{Ca}^{2+}$ and $\mathrm{Mg}^{2+}$ [35]. Water temperatures range from about $6^{\circ} \mathrm{C}$ in the winter to $18^{\circ} \mathrm{C}$ in summer.

Monitoring RHg in the Idrijca River was carried out to demonstrate the advantages of the ethylation based method. In the past, $\mathrm{Sn}^{2+}$ reduction has been the only method for measuring $\mathrm{RHg}$ at the site. Since the riverdrains the area of the former $\mathrm{Hg}$ mine, the water contains a significant amount of $\mathrm{Hg}^{0}$ [15]. To eliminate the positive bias caused by naturally occurring $\mathrm{Hg}^{0}$, the samples

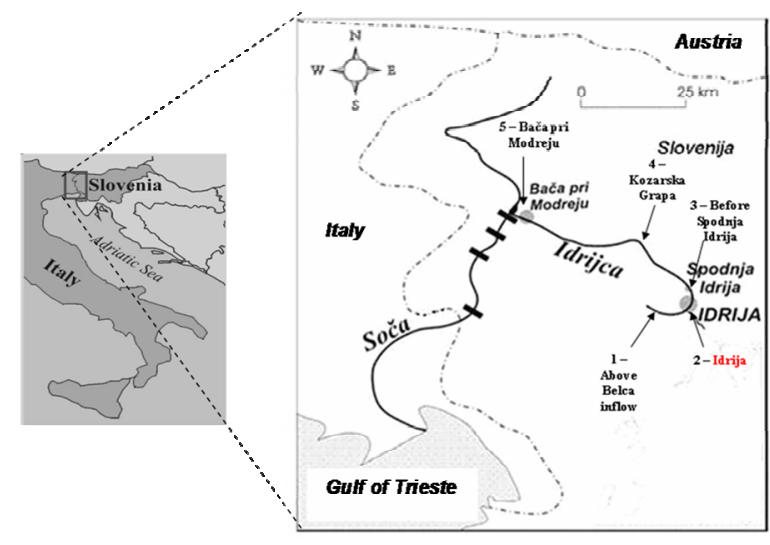

Figure 7. Sampling locations on the river Idrijca. 
were pre-purged prior to adding the $\mathrm{Sn}^{2+}$ reagent. However, purging for 10 to $20 \mathrm{~min}$ might not be enough to completely remove naturally occurring $\mathrm{Hg}^{0}$ from highly contaminated samples like these (THg up to $650 \mathrm{ng} / \mathrm{L}$ ), and a positive bias might result. In contrast to this positive bias, negative bias might be introduced in the subsequent $\mathrm{Sn}^{2+}$ reduction of $\mathrm{RHg}$ due to an insufficient purge of $\mathrm{Sn}^{2+}$-reduced $\mathrm{Hg}^{0}$. As a result, the data might be highly variable and uncertain due to both positive and negative bias effects. When the ethylation based method was used, neither positive nor negative bias effects were encountered.

To examine whether the ethylation method can generate results meaningful for the characterization of $\mathrm{Hg}$ speciation in this river, water samples from the five locations were collected in the summer of 2012. Filtration was performed immediately after sample collection at all sites. Both filtered and unfiltered samples were analyzed for THg, MeHg, and EtRHg. Results for RHg determined using the ethylation based method and for other $\mathrm{Hg}$ species measured in the same samples are shown in Figure 8. Concentrations of the various species at the five sampling locations were compared and found to vary in ways consistent with each other in response to changes in dilution, mixing, rainfall, etc.

For all $\mathrm{Hg}$ species/fraction, the highest concentrations were found at the location of the Idrija $\mathrm{Hg}$ mine, and concentrations decreased downstream but in different patterns for the different $\mathrm{Hg}$ species/fraction. The $\mathrm{THg}$ concentration dropped quickly within a relatively short distance (about $10 \mathrm{~km}$ ), then gradually decreased, approaching the RHg concentration. This indicates that, in addition to $\mathrm{RHg}$, $\mathrm{THg}$ includes other $\mathrm{Hg}$ species such as $\mathrm{Hg}^{0}, \mathrm{HgS}, \mathrm{Hg}_{2} \mathrm{Cl}_{2}, \mathrm{HgSe}$, etc. In the river, $\mathrm{Hg}^{0}$ evasion and the adsorption/precipitation of $\mathrm{HgS}, \mathrm{Hg}_{2} \mathrm{Cl}_{2}$, and $\mathrm{HgSe}$ may take place, resulting in decreasing THg con-

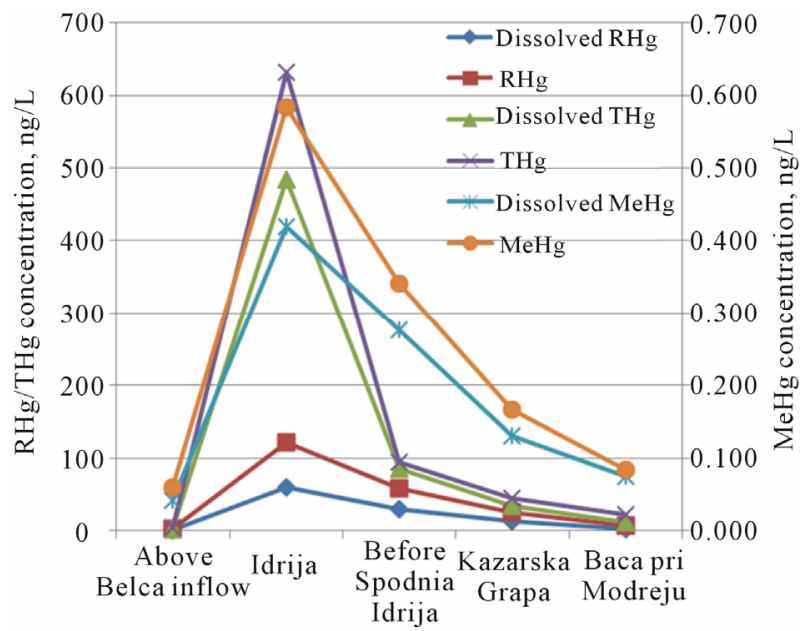

Figure 8. Concentrations of $\mathrm{Hg}$ species/fractions measured in the River Idrija in Slivenia. centrations which gradually approach the RHg concentration. In this particular case, $\mathrm{Hg}^{0}$ evasion enhanced by the turbulent, torrential nature of the river is likely the major cause of the dramatic decrease in the THg concentration downstream from the $\mathrm{Hg}$ mine. Compared to $\mathrm{THg}$, $\mathrm{RHg}$ concentrations vary differently and in a pattern that was not affected by $\mathrm{Hg}^{0}$ evasion. Concentrations of $\mathrm{MeHg}$ decreased downstream of the mine, but in another, different pattern compared to both $\mathrm{THg}$ and $\mathrm{RHg}$.

\section{Conclusion}

This work has identified and characterized appropriate and reliable analytical methods capable of producing accurate, precise, and meaningful results for RHg. The positive and negative biases that can arise in using the $\mathrm{Sn}^{2+}$ reduction method for the determination of $\mathrm{RHg}$ have been described, and the use of the alternative ethylation GC-CVAFS method is recommended. Using the ethylation based method, it is confident that results generated are the biogeochemically reactive fractions of $\mathrm{Hg}^{2+}$. As any good measurements always can promote the research growing up, it is believed that the discovery of the analytical problems using the $\mathrm{Sn}^{2+}$ reduction method for determination of RHg will draw significant attention from environmental researchers in the world. Once the problems outlined in this work are recognized and the ethylation based GC-CVAFS method is used, measurement of $\mathrm{RHg}$ will become widespread because it will provide the researchers with meaningful data. It is believed that a breakthrough in the research of $\mathrm{Hg}$ biogeochemistry is a possible outcome.

\section{Acknowledgements}

The work was partially funded by the Slovenian Research Agency (ARRS) through programme P1-0143 and project J1-4288, and also supported by Chevron Energy Technology Company under Contract CW831200. V. We thank Fajon for sampling the water samples from the river Idrijca.

\section{REFERENCES}

[1] T. W. Clarkson and L. Magos, "The Toxicology of Mercury and Its Chemical Compounds," Critical Reviews in Toxicology, Vol. 36, No. 8, 2006, pp. 609-662. http://dx.doi.org/10.1080/10408440600845619

[2] T. Barkay and I. Wagner-Dobler, "Microbial Transformations of Mercury: Potentials, Challenges, and Achievements in Controlling Mercury Toxicity in the Environment," In: A. I. Laskin, J. W. Bennett and G. M. Gadd, Eds., Advances in Applied Microbiology, Vol. 57, Elsevier Academic Press Inc., San Diego, 2005, pp. 1-52.

[3] M. Horvat, J. Snoj Tratnik and A. Miklavcic, "Mercury: Biomarkers of Exposure and Human Biomonitoring," In: 
L. E. Knudsen and D. F. Merlo, Eds., Biomarkers and Human Biomonitoring, Issues in Toxicology, No. 9, RSC Publishing, Cambridge, 2012, pp. 381-417.

[4] M. C. Newman, X. Y. Xu, A. Condon and L. Liang, "Floodplain Methylmercury Biomagnification Factor Higher than That of the Contiguous River (South River, Virginia USA)," Environmental Pollution, Vol. 159, No. 10, 2011, pp. 2840-2844. http://dx.doi.org/10.1016/j.envpol.2011.04.045

[5] J. C. Wang, M. C. Newman, X. Y. Xu and L. Liang, "Higher and More Variable Methylmercury Biomagnification Factors for Floodplain Than the Contiguous River (South River, Virginia USA)," Ecotoxicology and Environmental Safety, 2013.

http://dx.doi.org/10.1016/j.ecoenv.2012.04.023i

[6] H. Hsu-Kim, K. H. Kucharzyk, T. Zhang and M. A. Deshusses, "Mechanisms Regulating Mercury Bioavailability for Methylating Microorganisms in the Aquatic Environment: A Critical Review," Environmental Science \& Technology, Vol. 47, No. 6, 2013, pp. 2441-2456. http://dx.doi.org/10.1021/es304370g

[7] J. K. Schaefer, S. S. Rocks, W. Zheng, L. Y. Liang, B. H. $\mathrm{Gu}$ and F. M. M. Morel, "Active Transport, Substrate Specificity, and Methylation of $\mathrm{Hg}(\mathrm{II})$ in Anaerobic Bacteria," Proceedings of the National Academy of Sciences, Vol. 108, No. 21, 2011, pp. 8714-8719. http://dx.doi.org/10.1073/pnas.1105781108

[8] W. Zheng, L. Y. Liang and B. H. Gu, "Mercury Reduction and Oxidation by Reduced Natural Organic Matter in Anoxic Environments," Environmental Science \& Technology, Vol. 46, No. 1, 2012, pp. 292-299.

http://dx.doi.org/10.1021/es203402p

[9] M. E. Hines, J. Faganeli, I. Adatto and M. Horvat, "Microbial Mercury Transformations in Marine, Estuarine and Freshwater Sediment Downstream of the Idrija Mercury Mine," Applied Geochemistry, Vol. 21, No. 11, 2006, pp. 1924-1939.

http://dx.doi.org/10.1016/j.apgeochem.2006.08.008

[10] N. S. Bloom, "Influence of Analytical Conditions on the Observed 'Reactive Mercury', Concentrations in Natural Fresh Waters," In: J. Huckabee and C. J. Watras, Eds., Mercury as a Global Pollutant, Lewis Publishers, Ann Arbor, 1994.

[11] J. D. Dean and R. P. Mason, "Estimation of Mercury Bioaccumulation Potential fromWastewater Treatment Plants in Receiving Waters: Phase II," Final Report, 2009, 05WEM-1COa, WERF, Co-published by IWA Publishing.

[12] S. Rapsomanikis, O. F. X. Donard and J. H. Weber, "Speciation of Lead and Methyllead Ions in Water by Chromatography/Atomic Absorption Spectrometry after Ethylation with Sodium Tetraethylborate," Analytical Chemistry, Vol. 58, No. 1, 1986, pp. 35-38. http://dx.doi.org/10.1021/ac00292a011

[13] N. S. Bloom, "Determination of Pictogram Levels of Methylmercury by Aqueous Phase Ethylation, Followed by Cryogenic Gas Chromatography with Cold Vapor Atomic Fluorescence Detection," Canadian Journal of Fisheries and Aquatic Sciences, Vol. 46, No. 7, 1989, pp. 11311140. http://dx.doi.org/10.1139/f89-147
[14] L. Liang, M. Horvat and N. S. Bloom, "An Improved Speciation Method for Mercury by GC/CVAFS after Aqueous Phase Ethylation and Room Temperature Precollection," Talanta, Vol. 41, No. 3, 1994, pp. 371-379. http://dx.doi.org/10.1016/0039-9140(94)80141-X

[15] S. Žižek, R. Milačič, R. Jaćimivić, M. J. toman and M. Horvat, "Periphyton as a Bioindicator of Mercury Pollution in a Temperate Torrential River Ecosystem," Chemosphere, Vol. 85, No. 5, 2011, pp. 883-891. http://dx.doi.org/10.1016/j.chemosphere.2011.06.110

[16] W. R. Hatch and W. L. Ott, "Determination of Sub-Cold Vapour Atomic Absorption Spectrophotometry," Analytical Chemistry, Vol. 40, No. 14, 1968, pp. 2085-2087. http://dx.doi.org/10.1021/ac50158a025

[17] L. Liang, Bloom and M. Horvat, "Simultaneous Determination of Mercury Speciation in Biological Materials by GC/CVAFS after Ethylation and Room Temperature Precollection," Clinical Chemistry, Vol. 40, No. 4, 1994, pp. 602-607.

[18] L. Liang, C. Evens, S. Lazoff, J. S. Woods, E. Cernichiari, M. Horvat, M. D. Martin and T. DeRouen, "Determination of Methyl Mercury in Whole Blood by EthylationGC-CVAFS after Alkaline Digestion-Solvent Extraction," Journal of Analytical Toxicology, Vol. 24, No. 5, 2000, pp. 328-332. http://dx.doi.org/10.1093/jat/24.5.328

[19] US EPA Method 1669, "Sampling Ambient Water for Trace Metals at EPA Water Quality Criteria Levels," Washington, DC, 1996.

[20] US EPA 1631, "Mercury in Water by Oxidation, Purge and Trap, and Cold Vapor Atomic Fluorescence Spectrometry," Environmental Protection Agency, Washington, DC, 2002.

[21] US EPA 1630, "Methyl Mercury in Water by Distillation, Aqueous Ethylation," US Environmental Protection Agency, Washington, DC, 2001.

[22] L. Liang and N. S. Bloom, "Determination of Total Mercury by Single-Stage Gold Amalgamation with Cold Vapor Atomic Spectrometry," JAAS, Vol. 8, 1993, pp. 591594.

[23] M. Horvat, "Determination of Mercury and Its Compounds in Water, Sediment, Soil and Biological Samples," In: N. Pirrone and K. R. Mahaffey, Eds., Dynamics of Mercury Pollution on Regional and Global Scales: Atmospheric Processes and Human Exposures around the World, Springer, New York, 2005, pp. 154-190. http://dx.doi.org/10.1007/0-387-24494-8_8

[24] B. H. Gu, Y. R. Bian, C. L. Miller, W. M. Dong, X. Jiang and L. Y. Liang, "Mercury Reduction and Complexation by Natural Organic Matter in Anoxic Environments," Proceedings of the National Academy of Sciences, Vol. 108, No. 4, 2011, pp. 1479-1483. http://dx.doi.org/10.1073/pnas.1008747108

[25] W. M. Dong, L. Y. Liang, S. Brooks, G. Southworth and B. H. Gu, "Roles of Dissolved Organic Matter in the Speciation of Mercury and Methylmercury in an Contaminated Ecosystem in Oak Ridge," Tennessee Environmental, Vol. 7, No. 1, 2010, pp. 94-102.

[26] C. L. Miller, G. Southworth, S. Brooks, L. Y. Liang and B. H. Gu, "Kinetic Controls on the Complexation be- 
tween Mercury and Dissolved Organic Matter in a Contaminated Environment," Environmental Science \& Technology, 2009, Vol. 43, No. 22, 2009, pp. 8548-8553.

[27] M. Horvat, N. S. Bloom and L. Liang, "A Comparison of Distillation with Other Current Isolation Methods for Determination of Methyl Mercury Compounds in Low Level Environmental Samples, Part 1: Sediment," Analytica Chimica Acta, Vol. 281, No. 1, 1993, pp. 135-152. http://dx.doi.org/10.1016/0003-2670(93)85348-N

[28] M. Horvat, L. Liang and N. S. Bloom, "A Comparison of Distillation with Other Current Isolation Methods for the Determination of Methyl Mercury Compounds in Low Level Environmental Samples, Part 2: Water," Analytica Chimica Acta, Vol. 282, No. 1, 1993, pp. 153-168. http://dx.doi.org/10.1016/0003-2670(93)80364-Q

[29] L. Liang, M. Berndt, T. K. Bavin and P. Pang, "Definition and Application of Alkylatable Mercury (AHg) for Estimation of Bioavailable Mercury," 9th ICMGP, Guiyang, June 7-12, 2009, pp. S19-52.

[30] L. Liang, D. Hwang, L. Young, E. A. Aultman and P. Pang, "The Use of Alkylatable Mercury for Risk Assessment and Remediation Evaluation of $\mathrm{Hg}$ Contaminated Water/Soil/Sediment," 10th ICMGP, Halifax, Nova Scotia, July 24-29, 2011.

[31] K. Matsunaga, S. Konishi and M. Nishimura, "Possible errors Caused Prior to Measurement of Mercury in Natural Waters with Special Reference to Seawater," Environmental Science \& Technology, Vol. 13, No. 1, 1979, pp. 63-70. http://dx.doi.org/10.1021/es60149a013

[32] J. A. Dalziel and P. A. Yeats, "Reactive Mercury in the Central North Atlantic Ocean," Marine Chemistry, Vol. 15 , No. 4, 1985, pp. 357-365. http://dx.doi.org/10.1016/0304-4203(85)90046-5

[33] N. S. Bloom and E. A. Crecelius, "Determination of Mercury in Seawater at Subnanogram per Liter Levels," Marine Chemistry, Vol. 14, No. 1, 1983, pp. 59-64. http://dx.doi.org/10.1016/0304-4203(83)90069-5
[34] G. A. Gill and W. F. Fitzgerald, "Picomolar Mercury Measurements in Seawater and Other Materials Using Stannous Chloride Reduction and Two Stage Gold Amalgamation with Gas Phase Detection," Marine Chemistry, Vol. 20, No. 3, 1987, pp. 227-243. http://dx.doi.org/10.1016/0304-4203(87)90074-0

[35] T. Kanduc, D. Kocman and N. Ogrinc, "Hydrogeochemical and Stable Isotope Characteristics of the River Idrijca (Slovenia), the Boundary Watershed between the Adriatic and Black Seas," Marine Chemistry, Vol. 14, No. 3, 2008, pp. 239-262. http://dx.doi.org/10.1007/s10498-008-9035-2

[36] M. E. Hines, M. Horvat, J. Faganeli, J. C. J. Bonzongo, T. Barkay, E. B. Major, K. J. Scott, E. A. Bailey, J. J. Warwick and W. B. Lyons, "Mercury Biogeochemistry in the Idrija River, Slovenia, from above the Mine into the Gulf of Trieste," Environmental Research, Vol. 83, No. 2, 2000, pp. 129-139. http://dx.doi.org/10.1006/enrs.2000.4052

[37] M. Horvat, S. Covelli, J. Faganeli, M. Logar, V. Mandic, R. Rajar, A. Sirca and D. Zagar, "Mercury in Contaminated Coastal Environments, a Case Study: The Gulf of Trieste," Science of The Total Environment, Vol. 237-238, 1999, pp. 43-56. http://dx.doi.org/10.1016/S0048-9697(99)00123-0

[38] M. Horvat, V. Jereb, V. Fajon, M. Logar, J. Kotnik, J. Faganeli, M. E. Hines and J.-C. Bonzongo, "Mercury Distribution in Water, Sediment and Soil in the Idrijca and Soča River Systems," Geochemistry: Exploration, Environment, Analysis, Vol. 2, No. 3, 2002, pp. 287-296. http://dx.doi.org/10.1144/1467-787302-033

[39] D. Kocman, T. Kanduc, N. Ogrinc and M. Horvat, "Distribution and Partitioning of Mercury in a River Catchment Impacted by Former Mercury Mining Activity," Biogeochemistry, Vol. 104, No. 1-3, 2011, pp. 183-201. http://dx.doi.org/10.1007/s10533-010-9495-5 